\title{
NOTES
}

\section{Biochemical Properties of Bacteroides melaninogenicus Subspecies}

\author{
R. A. D. WILliaMS, G. H. BOWDEN, J. M. HARDIE, AND H. SHAH \\ Department of Biochemistry and Dental Bacteriology Laboratory, The London Hospital Medical College, \\ London, England
}

Three subspecies of Bacteroides melaninogenicus differ from one another in cell wall composition, malate dehydrogenase mobility, deoxyribonucleic acid base composition, and physiological tests.

Bacteroides melaninogenicus is commonly found in mixed infections (9) and has been shown to be an essential component of some artificially induced mixed anaerobic infections (16). By adolescence, B. melaninogenicus is of almost universal occurrence in the human mouth, although it is only occasionally isolated from the mouths of young children (2). However, strains called $B$. melaninogenicus have been isolated from many sites and allocated to three subspecies. If there are significant biochemical differences between these subspecies, it becomes important to know whether they occur in different ecological niches and to ensure that, for example, oral strains are used in studies which may implicate the appropriate type of $B$. melaninogenicus in oral infections.

In the present study, the biochemical properties of seven strains of the three subspecies of B. melaninogenicus have been compared (Table 1). One strain (T588) is typical of the dental plaque strains isolated so far in this laboratory and closely resembles NCTC 9338 . This strain has been examined in the Anaerobic Laboratory, Virginia Polytechnic Institute (VPI 9144), and its status as $B$. melaninogenicus subsp. intermedius was confirmed (L. Holdeman, personal communication). The three strains representing $B$. melaninogenicus subsp. asaccharolyticus are all of intestinal origin. Strain B536, originally isolated by S. Finegold, was obtained from E. M. Barnes.

Strains were maintained on plates containing $5 \%$ defibrinated horse blood and $1 \%$ agar (preincubated anaerobically before use). Colonies of B. melaninogenicus subsp. asaccharolyticus took longer to become black than those of $B$. melaninogenicus subsp. intermedius or $B$. melaninogenicus subsp. melaninogenicus and also had a more mucoid appearance, although a hematin pigment could be extracted from black cells of both types (15). Slight red fluorescence (12) was observed with young cultures of $B$. melaninogenicus subsp. asaccharolyticus, but not in the other subspecies where it may have been quenched by the rapidly forming black pigment. Liquid cultures contained $1 \%$ Trypticase (BBL), $1 \%$ proteose peptone $(\mathrm{Ox}$ oid), $0.5 \%$ yeast extract (Difco), $1 \%$ glucose, $0.5 \%$ sodium chloride, and $0.075 \%$ cysteine hydrochloride. The $\mathrm{pH}$ was adjusted to 7.4 , and the medium was autoclaved at $121 \mathrm{C}$ for $15 \mathrm{~min}$. Filter-sterilized bovine serum (Oxoid) and menadione-hemin solution (7) were added aseptically to provide final concentrations of 2 and $1 \%$ (vol/vol), respectively, together with a few drops of sterile $10 \%$ sodium carbonate. Plates and bottles were incubated in anaerobic jars containing $95 \%$ hydrogen plus $5 \% \quad \mathrm{CO}_{2}$. Larger liquid cultures were grown in $500-\mathrm{ml}$ or 1-liter bottles which were completely filled with sterile medium after inoculation and tightly sealed. Fermentation tests were carried out using the above medium with $1 \%$ of the appropriate filter-sterilized carbohydrate in place of glucose. The physiological tests which most clearly distinguished $B$. melaninogenicus subsp. asaccharolyticus and $B$. melaninogenicus subsp. intermedius were the hydrolysis of starch and the fermentation of glucose and maltose. Only $B$. melaninogenicus subsp. melaninogenicus hydrolyzed esculin.

Glucose utilization and the production of metabolic end products were estimated using the above medium, with proteose peptone in place of Trypticase, after anaerobic incubation for 4 days. Cells were harvested, and the residual glucose in the medium was estimated by the hexokinase-glucose-6-phosphate dehydrogenase procedure (Boehringer-Mannheim $\mathrm{GmbH}$ ), 
TABLE 1. Properties of strains of B. melaninogenicus ${ }^{a}$

\begin{tabular}{|c|c|c|c|c|c|c|c|}
\hline \multirow{2}{*}{ Property } & \multicolumn{3}{|c|}{$\begin{array}{l}\text { B. melaninogenicus subsp. } \\
\text { asaccharolyticus }\end{array}$} & \multirow{2}{*}{$\begin{array}{c}\begin{array}{c}\text { B. melanino- } \\
\text { genicus } \\
\text { subsp. } \\
\text { melanino- } \\
\text { genicus }\end{array} \\
\begin{array}{c}\text { VPI } 9085(2) \\
\text { (Gingival } \\
\text { crevice) }\end{array}\end{array}$} & \multicolumn{3}{|c|}{$\begin{array}{l}\text { B. melaninogenicus subsp. } \\
\text { intermedius }\end{array}$} \\
\hline & $\begin{array}{c}\text { NCTC } 9337 \\
\text { Infected } \\
\text { hemor- } \\
\text { rhoids }^{\circ}\end{array}$ & $\begin{array}{l}\text { VPI } 4199 \\
\text { Stools }\end{array}$ & B536 Stools & & $\begin{array}{l}\text { NCTC } 9336 \\
\text { Vincents } \\
\text { gingivitis }\end{array}$ & $\begin{array}{l}\text { NCTC } 9338 \\
\text { Empyema }\end{array}$ & $\begin{array}{c}\text { T588 } \\
\text { Human } \\
\text { dental } \\
\text { plaque } \\
\end{array}$ \\
\hline $\begin{array}{l}\text { Days taken to become } \\
\text { black }\end{array}$ & $8-10$ & $8-10$ & $8-10$ & $5-8$ & $3-4$ & $3-4$ & $3-4$ \\
\hline Esculin hydrolysis & - & - & - & + & - & - & - \\
\hline Starch hydrolysis & - & - & - & + & + & + & + \\
\hline $\mathrm{pH}, 1 \%$ glucose & 6.5 & 6.2 & 7.0 & 5.1 & 5.0 & 4.7 & 4.4 \\
\hline $\mathrm{pH}, 1 \%$ maltose & 6.1 & 5.9 & 5.9 & 4.9 & 4.7 & 4.8 & 4.6 \\
\hline $\begin{array}{l}\text { Utilization of } 0.5 \% \text { glucose } \\
\quad(\%) \\
\text { Acid end products }\end{array}$ & 28 & 34 & 24 & 27 & 44 & 36 & 90 \\
\hline Acetic & + & + & + & + & + & + & + \\
\hline Propionic & + & + & + & - & - & - & - \\
\hline Iso-butyric & + & + & + & - & + & + & + \\
\hline$n$-Butyric & + & + & + & - & - & - & - \\
\hline Iso-valeric & + & + & + & - & + & + & + \\
\hline Lactic & + & + & + & - & + & + & + \\
\hline Succinic & - & - & - & + & + & + & + \\
\hline Mobility of MDH $(\mathrm{cm})$ & 4.8 & 4.8 & 4.8 & 3.8 & 4.3 & 4.3 & 4.3 \\
\hline $\begin{array}{l}\text { Basic amino acid of muco- } \\
\text { peptide }\end{array}$ & Lysine & Lysine & Lysine & Lysine & DAP & DAP & DAP \\
\hline$\underset{\text { DNA (\%) }}{\text { Guanine }}+$ cytosine in & 50.0 & 50.7 & 50.9 & 45.8 & 42.7 & 41.2 & 43.6 \\
\hline
\end{tabular}

${ }^{a}$ DNA, Deoxyribonucleic acid; DAP, diaminopimelic acid (DL isomer); $\mathrm{MDH}$, malate dehydrogenase.

b Source.

with the exception that after deproteinization the supernatant was diluted fivefold. Utilization of glucose occurred to some extent in all subspecies, including $B$. melaninogenicus subsp. asaccharolyticus strains, which caused little fall of $\mathrm{pH}$ in fermentation tests.

Gas-liquid chromatography for volatile end products was carried out on ether extracts of medium acidified to $\mathrm{pH} 2$ with sulphuric acid (4). Strains were also examined for volatile fatty acids together with lactic and succinic acids, using the chromatographic system described by Carlsson (3). The acid profiles were characterized by the lack of propionic and $n$-butyric acids among the metabolic end products of $B$. melaninogenicus subsp. intermedius strains, as noted previously (7), and by the absence of detectable succinic acid among the end products of $B$. melaninogenicus subsp. asaccharolyticus. Strain 9085 (2) produced acetic and succinic acids only.

Cell-free extracts were prepared either by shaking with Ballotini beads in a Mickle tissue disintegrator or by pressing once with a Biox pressure cell. After removing debris by centrifugation, extracts were electrophoresed on Cellogel strips (14 by $7.5 \mathrm{~cm}$; Reeve Angel Scientific
Ltd.) in barbitone-acetate buffer, $0.04 \mathrm{M}, \mathrm{pH}$ 8.6 , for $1 \mathrm{~h}$ at a voltage gradient of $10 \mathrm{~V} / \mathrm{cm}$. Phenol red indicator migrated $8 \mathrm{~cm}$ under these conditions. Malate dehydrogenase was stained using $2 \mathrm{mg}$ of malic acid per $\mathrm{ml}, 0.04 \mathrm{mg}$ of phenazine methosulfate per $\mathrm{ml}, 0.2 \mathrm{mg}$ of thiazolyl blue tetrazolium per $\mathrm{ml}$, and 0.1 $\mathrm{mg}$ of nicotinamide adenine dinucleotide per $\mathrm{ml}$ in $0.08 \mathrm{M}$ tris(hydroxymethyl)aminomethane buffer ( $\mathrm{pH} 7.5$ ). Single bands of enzyme were found in all strains, but those of $B$. melaninogenicus subsp. asaccharolyticus migrated significantly faster than those of $B$. melaninogenicus subsp. intermedius, which in turn were more mobile than $B$. melaninogenicus subsp. melaninogenicus. A mixture of extracts of three subspecies resolved into three bands, but mixtures of several strains of $B$. melaninogenicus subsp. intermedius, or of strains of $B$. melaninogenicus subsp. asaccharolyticus, did not so resolve. Cell walls were prepared by the rapid method of Schleifer and Kandler (14) and hydrolyzed overnight with $4 \mathrm{~N} \mathrm{HCl}$. Analysis was by paper chromatography in two dimensions (6), in the solvent (13) for the detection of diaminopimelic acid isomers, and by high voltage electrophoresis in the $\mathrm{pH} 5.2$ 
pyridine-acetic acid buffer (1). The significant finding was the presence of two different dibasic amino acids in the three subspecies. The occurrence of diaminopimelic acid in $B$. melaninogenicus subsp. intermedius distinguishes this group from all the Bacteroides strains tested so far in this laboratory, including representatives of $B$. oralis and $B$. fragilis.

Cells possessing the lysine-mucopeptide type lysed readily with sodium dodecyl sulfate. The diaminopimelic acid-containing strains were rendered susceptible to lysis by growing them in the presence of $1 \%$ glycine (17). Deoxyribonucleic acid purification was based on the method of Marmur (10), except that the crude lysate was treated with proteinase $\mathrm{K}$ (Merck), 50 $\mathrm{mg} / \mathrm{ml}$, at $37 \mathrm{C}$ for $16 \mathrm{~h} \mathrm{(5).} \mathrm{This} \mathrm{treatment}$ reduced the number of deproteinization steps necessary to produce pure deoxyribonucleic acid and also improved the yield. Base composition was estimated by thermal denaturation (11). There is a significant difference between the mean base composition of $B$. melaninogenicus subsp. intermedius and that in $B$. melaninogenicus subsp. asaccharolyticus.

The results of this study indicate that there are substantial differences between strains of $B$. melaninogenicus subsp. asaccharolyticus and B. melaninogenicus subsp. intermedius, and it may in the future be considered inappropriate for them to be retained within the same species. Although only a small number of strains have been examined to date, it is possible that there may be an ecological difference between these subspecies, subsp. asaccharolyticus strains being derived from gut specimens and examples of $B$. melaninogenicus subsp. intermedius having been obtained mainly from oral samples.

Examples of B. melaninogenicus subsp. melaninogenicus are apparently difficult to obtain, and so far only one strain of this type has been examined. Further strains must be studied to confirm the difference in properties of this subspecies (Table 1). The ability to hydrolyze esculin (7) appears to offer the simplest method of detecting such strains.

The methods reported in this communication will be used to characterize a collection of black-pigmented Bacteroides strains isolated from oral specimens to establish which of the subspecies of $B$. melaninogenicus are prevalent in the mouth.

\section{REPRINT REQUESTS}

Address reprint requests to: Dr. R. A. D. Williams, Department of Biochemistry and Dental Bacteriology Laboratory, The London Hospital Medical College, Turner St., London E1, England.

\section{LITERATURE CITED}

1. Atfield, G. N., and C. J. O. R. Morris. 1961. Analytical separations by high voltage electrophoresis. Amino acids in protein hydrolysates. Biochem. J. 81:606-614.

2. Bailit, H. L., D. C. Baldwin, and E. E. Hunt, Jr. 1964. Increasing prevalence of gingival Bacteroides melaninogenicus with age in children. Arch. Oral Biol. 9:435-438.

3. Carlsson, J. 1973. Simplified gas chromatographic procedure for identification of bacterial metabolic products. Appl. Microbiol. 25:287-289.

4. Doelle, H. W., and G. J. Manderson. 1969. Preparation of extracts of culture liquids for gas-chromatographic determination of acidic fermentation products. Antonie van Leeuwenhoek J. Microbiol. Serol. 35:467-478.

5. Gross-Bellard, M., P. Oudet, and P. Chambon. 1973. Isolation of high molecular weight DNA from mammalian cells. Eur. J. Biochem. 36:32-38.

6. Hardy, T. L., D. O. Holland, and J. H. C. Nayler. 1955. One-phase solvent mixtures for the separation of amino acids. Anal. Chem. 27:971-974.

7. Holdeman, L. V., and W. E. C. Moore. 1972. Anaerobe laboratory manual. Virginia Polytechnic Institute, Blacksburg, Va.

8. Kelstrup, J. 1966. The incidence of Bacteroides melaninogenicus in human gingival sulci, and its prevalence in the oral cavity at different ages. Periodontics 4:14.

9. Macdonald, J. B., R. M. Sutton, M. L. Knoll, E. M. Madlender, and R. M. Grainger. 1956. The pathogenic components of an experimental fuso-spirochaetal infection. J. Infect. Dis. 98:15-20.

10. Marmur, J. 1961. A procedure for the isolation of deoxyribonucleic acid from microorganisms. J. Mol. Biol. 3:208-218.

11. Marmur, J., and P. Doty. 1962. Determination of the base composition of deoxyribonucleic acid from its thermal denaturation temperature. J. Mol. Biol. 5:109-118.

12. Myers, M. B., G. Cherry, B. B. Bornside, and G. H. Bornside. 1969. Ultraviolet red fluorescence of Bacteroides melaninogenicus. Appl. Microbiol. 17:760-762.

13. Rhuland, L. E., E. Work, R. F. Denman, and D. S. Hoare 1955. The behaviour of isomers of $\alpha-\epsilon$ diaminopimelic acid on paper chromatograms. J. Am. Chem. Soc. 17:4844-4846.

14. Schleifer, K. H., and O. Kandler. 1972. Peptidoglycan types of bacterial cell walls and their taxonomic implications. Bacteriol. Rev. 36:407-477.

15. Schwabacher, H., and D. R. Lucas. 1947. Bacterium melaninogenicus: a misnomer. J. Gen. Microbiol. 1:109-121.

16. Socransky, S. S., and R. J. Gibbons. 1965. Required role of Bacteroides melaninogenicus in mixed anaerobic infections. J. Infect. Dis. 115:247-253.

17. Yamada, K., and K. Komagata. 1970. Taxonomic studies on coryneform bacteria. III. DNA base composition of coryneform bacteria. J. Gen. Appl. Microbiol. $16: 215-224$. 